\title{
Surface mass balance and stable oxygen isotope ratios from shallow firn cores on Fimbulisen, East Antarctica
}

\author{
E. SCHLOSSER, ${ }^{1}$ H. ANSCHÜTZ, ${ }^{2}$ E. ISAKSSON, ${ }^{3}$ T. MARTMA, ${ }^{4}$ D. DIVINE, ${ }^{5}$ \\ O.-A. NØST ${ }^{3}$
}

${ }^{1}$ Institute of Meteorology and Geophysics, University of Innsbruck, Innsbruck, Austria

E-mail: elisabeth.schlosser@uibk.ac.at

${ }^{2} \mathrm{NGI}$ Oslo, Oslo, Norway

${ }^{3}$ Norwegian Polar Institute, Tromsø, Norway

${ }^{4}$ Institute of Geology, Tallinn University of Technology, Tallinn, Estonia

${ }^{5}$ Department of Mathematics and Statistics, University of Tromsø, Tromsø, Norway

\begin{abstract}
The mass balance of Antarctica is one of the crucial factors for determining sea-level change in a warming climate. The marginal zones of the continent, namely the ice shelves, are most sensitive to climate change. During the 2009/10 austral summer an extensive glaciological field campaign was carried out on Fimbulisen, an ice shelf in East Antarctica, to investigate its recent surface mass balance. Shallow (10-18 m) firn cores were drilled and accumulation rates and stable-isotope ratios determined. For firn-core dating, two different methods were compared: (1) seasonal variations of stable oxygen isotope ratios $\left(\delta^{18} \mathrm{O}\right)$, and (2) dielectric profiling, including using the volcanic eruptions of Pinatubo, Philippines (1991), and El Chichón, Mexico (1982), as time markers. The mean annual accumulation for the period 1992-2009 ranges from 298 to $349 \mathrm{~mm}$ w.e. $\mathrm{a}^{-1}$. The interannual variability at the drilling sites is $>30 \%$. Accumulation rates show a weak decreasing trend during the past 20-30 years, which is statistically significant only for one of the cores. Stable-isotope ratios were compared to the snowfall temperature of Neumayer station. Neither the temperatures nor the $\delta^{18} \mathrm{O}$ values show any trend for the investigated time period.
\end{abstract}

\section{INTRODUCTION}

The mass balance of Antarctica is one of the crucial factors for determining sea-level change in a warming climate. Higher precipitation due to higher saturation vapour pressure of warmer air could mitigate sea-level rise (e.g. Oerlemans, 1982). However, recent studies find no or only weak evidence for increase in temperature and/or surface mass balance (SMB). Combining modelling with field data, Monaghan and others (2006) investigated possible trends in Antarctic precipitation since the International Geophysical Year (IGY, 1957/58) and found no increase in the past 50 years. Accumulation studies with shallow firn cores find both positive and negative trends depending on the region and time period investigated (e.g. Isaksson and Melvold, 2002). Contradictory results have been found for the behaviour of temperature. Apart from the Antarctic Peninsula, which clearly shows a strong warming trend during the past century, only weak and often statistically insignificant near-surface temperature trends are found, the sign of the trend being dependent on the investigation period (e.g. Turner and others, 2005; Monaghan and others, 2008). Generally, the spatial interpolation between the few available stations remains a problem, in spite of the use of highresolution numerical models.

The marginal zones of the continent, namely the ice shelves, are the regions that are most sensitive to climate change. They are located in a temperature regime where positive temperatures and melting of snow already occur in the present climate (Kaczmarska and others, 2006). Thus, small changes in temperature and/or precipitation can have a large effect on the mass balance. Since ice shelves are in hydrostatic equilibrium with the ocean, the mass-balance change itself is not important quantitatively but as an indicator of climate change. Even more relevant is the strong influence the ice shelves have on ice-sheet dynamics and glacier outflow, especially in West Antarctica (Jenkins and others, 2010). Thus it is important to monitor the present conditions and possible recent changes on the ice shelves as exactly as possible. In this study, we present results from four shallow firn cores drilled on Fimbulisen, Dronning Maud Land (DML), in the 2009/10 austral summer, which cover approximately the past three decades. This study is part of a larger project, 'Fimbulisen top-to-bottom', with the overall aim of determining the total mass balance of the ice shelf combining glaciological and oceanographic methods (http:// fimbul.npolar.no).

\section{FIELD AREA AND PREVIOUS WORK}

Fimbulisen is one of the ice shelves that bound DML and is centred approximately at the Greenwich Meridian, with a north-south extent from $69.5^{\circ} \mathrm{S}$ to $71.5^{\circ} \mathrm{S}$ (see Fig. 1b). It is the largest ice shelf in the King Haakon VII Sea, the part of the Southern Ocean that borders DML in the north. The central part of the ice shelf is fed by Jutulstraumen, the largest outlet glacier in DML. Jutulstraumen drains an area of $124000 \mathrm{~km}^{2}$, and the ice velocity is $\sim 1 \mathrm{~km} \mathrm{a}^{-1}$ at the grounding line.

Jutulstraumen causes the build-up of a fast-moving tongue within the ice shelf, Trolltunga (Fig. 1), surrounded by slowermoving ice to the west and east. Trolltunga sticks out into the sea at its northern end, which might lead to an accumulation regime slightly different from the rest of the ice shelf, due to higher wind speeds and possibly slightly higher temperatures because of the surrounding ocean water. 
Scientific investigations of Fimbulisen started with the British-Norwegian-Swedish Expedition in 1949-52 (Swithinbank, 1957), during which a variety of glaciological measurements on ice shelves in DML (Quarisen, Ekströmisen and Fimbulisen; Fig. 1) were carried out. Quarisen and Ekströmisen are two small ice shelves west of Fimbulisen Quarisen being situated west of Ekströmisen $\left(71^{\circ} \mathrm{S}, 8^{\circ} \mathrm{W}\right)$ at approximately $\left.71^{\circ} \mathrm{S}, 10^{\circ} \mathrm{W}\right)$. Important glaciological research was also conducted during the overwintering at Norway Station (1956-60), situated on the western edge of Fimbulisen, close to the South African base SANAE III (Lunde, 1961). More recently, Norwegian groups have worked on Fimbulisen and Jutulstraumen as part of the Norwegian Antarctic Research Expedition (NARE), mainly focusing on spatial and temporal variability of SMB using stakes, firn cores and radar measurements (e.g. Melvold and others, 1998; Melvold, 1999), ice dynamics (e.g. Rolstad and others, 2000) and climate-related studies using ice cores (Kaczmarska and others, 2004, 2006). Van den Broeke and others (1999) investigated variability of accumulation, temperature and wind along a traverse across Fimbulisen and related accumulation patterns to katabatic winds. (Katabatic winds can strongly influence spatial distribution of SMB by erosion of snow from the surface.) Also of interest is glaciological research on the ice shelf in the area of SANAE III in the 1960s (Neethling, 1970).

Previous work has suggested that both $\mathrm{SMB}$ and $\delta^{18} \mathrm{O}$ records from ice cores from this area contain a record of local climatic conditions, which determine the SMB pattern locally, in addition to the wider influence of sea-ice extent and the El Niño Southern Oscillation (ENSO); in spite of these local differences, there are similar overall decadal trends (Isaksson and Melvold, 2002; Divine and others, 2009). During NARE 2000/01, one $100 \mathrm{~m}$ deep ice core, S100, was drilled on eastern Fimbulisen (Fig. 1a) (Kaczmarska and others, 2004). This core covers the period AD 1737 2000 ( \pm 3 years) and is the longest among the available highresolution records from this part of coastal DML.

\section{FIELD METHODS AND DATA}

During the 2009/10 austral summer an extensive field programme was carried out on Fimbulisen in order to investigate the recent mass balance of the ice shelf. It included drilling of shallow firn cores, stake measurements for determining SMB and ice velocity, ice-penetrating radar measurements, and hot-water drilling for oceanographic measurements underneath the ice shelf. In this study we concentrate on the SMB of the western part of Fimbulisen by investigating shallow firn cores. In Figure 1 the location of the firn cores and the traverse route on Fimbulisen (Fig. 1b) are illustrated, together with a map of Antarctica that includes the stations with climate data discussed below (Fig. 1a). Table 1 shows the location, depth, time period, $10 \mathrm{~m}$ temperature and mean stable-isotope ratio of the four firn cores used in this study.

\section{Stable oxygen isotope ratios}

Stable oxygen isotope ratios $\left(\delta^{18} \mathrm{O}\right)$ of the firn cores (melted samples) were analysed in the Laboratory of Mass Spectrometry at the Institute of Geology, Tallinn University of Technology, using a Thermo Fisher Scientific Delta V Advantage mass spectrometer with Gasbench II. The sampling interval was $5 \mathrm{~cm}$, which ensures a good sub-annual
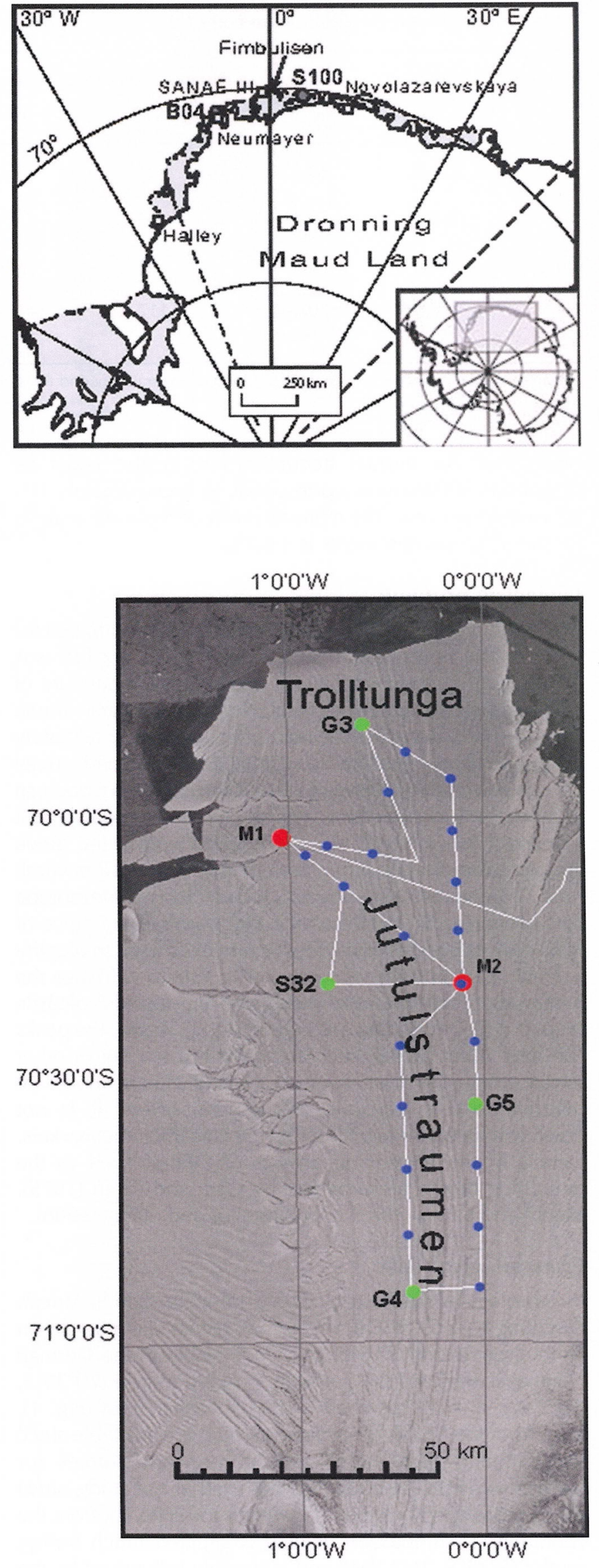

Fig. 1. (a) Location of Fimbulisen, weather stations, and older firn cores mentioned in the text (grey areas represent ice shelves). (b) Map of investigation area (Fimbulisen) with traverse route and location of firn cores. 
Table 1. Location and metadata of firn cores G3, G4, G5 and M2

\begin{tabular}{|c|c|c|c|c|c|c|c|c|}
\hline Firn core & $\begin{array}{l}\text { Long. } \\
{ }^{\circ} \mathrm{W}\end{array}$ & $\begin{array}{l}\text { Lat. } \\
{ }^{\circ} \mathrm{S}\end{array}$ & $\begin{array}{l}\text { Distance from coast } \\
\mathrm{km}\end{array}$ & $\begin{array}{c}\text { Elev. } \\
\text { ma.s.l. }\end{array}$ & $\begin{array}{l}\text { Length } \\
\mathrm{m}\end{array}$ & Time period & $\begin{array}{c}\text { Mean } \delta^{18} \mathrm{O} \\
\% 0\end{array}$ & $\begin{array}{c}10 \mathrm{~m} \text { firn temp. } \\
{ }^{\circ} \mathrm{C}\end{array}$ \\
\hline G3 & 0.612 & 69.823 & 27 & 57 & 10.0 & 1993-2009 & $\begin{array}{l}-19.7^{*} \\
-19.7^{\dagger}\end{array}$ & -16.3 \\
\hline M2 & 0.109 & 70.316 & 64 & 75 & 17.5 & 1983-2009 & $\begin{array}{l}-22.2^{*} \\
-21.7^{\dagger}\end{array}$ & -18.9 \\
\hline G5 & 0.041 & 70.545 & 83 & 82 & 14.5 & 1985-2009 & $\begin{array}{l}-22.0^{*} \\
-22.0^{\dagger}\end{array}$ & -19.2 \\
\hline G4 & 0.402 & 70.902 & 117 & 66 & 16.7 & 1984-2009 & $\begin{array}{l}-23.8^{*} \\
-23.7^{\dagger}\end{array}$ & -18.6 \\
\hline
\end{tabular}

${ }^{*}$ Mean over total core length. ${ }^{\dagger}$ Mean 1993-2009 (comparable period for all cores).

resolution. An annual accumulation in the order of magnitude $300 \mathrm{~mm}$ w.e. corresponds to approximately 10 12 samples per year. The reproducibility of replicate analysis for the $\delta^{18} \mathrm{O}$ measurements is $\pm 0.1 \%$.

\section{Dielectric profiling}

Dielectric profiling (DEP) measurements were conducted for the four firn cores. Electrical conductivity of the firn was determined in $5 \mathrm{~mm}$ intervals at a constant temperature of $-20^{\circ} \mathrm{C}$ in the cold laboratory of the Norwegian Polar Institute, Tromsø. The accuracy of the measurements is approximately $\pm 1 \%$ (Wilhelms and others, 1998). The a.c. conductivity reflects seasonal variations of various ions in the firn and can thus be used to date the cores by counting annual layers. However, the method has to be used with care, since apparent summer peaks may well be due to sea-salt maxima from single storm events. In cores for which no stable-isotope data are available, or for which the seasonal variations of $\delta^{18} \mathrm{O}$ cannot be resolved, DEP data are often used to identify volcanic peaks as time markers, to be able to calculate the mean accumulation rate between the found volcanic eruptions (e.g. Anschütz and others, 2009). Again, the peaks can have other causes, such as maxima in sea salt or other ions not related to volcanic eruptions, and without additional information (e.g. volcanic ash (tephra) layers) it is not possible to unambiguously define the volcanic time markers. Details of the underlying physics of DEP as well as the measuring device are provided by Glen and Paren (1975), Moore and others (1989) and Wilhelms and others (1998).

\section{Climatological data}

Meteorological data are available from the South African wintering base SANAE III (1959-92), which was situated on Fimbulisen itself $\left(70^{\circ} 18^{\prime} \mathrm{S}, 2^{\circ} 22^{\prime} \mathrm{W}\right)$, and from the German Neumayer station (1981-present) on Ekströmisen (70 39' S, $8^{\circ} 15^{\prime} \mathrm{W}$ ), a small ice shelf $\sim 200 \mathrm{~km}$ further west (Fig. 1). Data from the British base Halley, which are available since the IGY and have been used in previous studies for comparison with ice cores, are not used in our study, since the meteorological regime of Halley is too different from the conditions at Fimbulisen. Halley is situated much further south $\left(75^{\circ} 35^{\prime} \mathrm{S}, 26^{\circ} 34^{\prime} \mathrm{W}\right)$ and is strongly influenced by the year-round ice-covered Weddell Sea, which has consequences for both temperature and general atmospheric flow. The next station close to Fimbulisen to the east is the Russian base Novolazarevskaya. However, Novolazarevskaya is situated in an oasis rather than on an ice shelf and has a fairly particular local climate, which is altered by snow-free rocks and thus very different from SANAE and Neumayer, even though they are all under the same synoptic influences. Unfortunately, SANAE data are available only until 1992 since SANAE III was closed and SANAE IV was built at a different location further inland. Thus for comparison with $\delta^{18} \mathrm{O}$ profiles of the shallow firn cores we use annual mean air temperature from Neumayer station (1981-2010). Since the $\delta^{18} \mathrm{O}$ values only represent periods with snowfall, we calculated annual mean temperatures for snowfall conditions using the 3 hourly SYNOP data from Neumayer.

\section{RESULTS}

\section{Dating of the cores}

For the calculation of annual accumulation rates an accurate dating of the cores is necessary. Seasonal variations both of $\delta^{18} \mathrm{O}$ and of conductivity from DEP measurements were used to date the cores.

Figure 2 illustrates the stable oxygen isotope profiles $\left(\delta^{18} \mathrm{O}\right)$ of the cores. Seasonal variations are clearly visible, enabling annual layers to be counted. By comparing the stable-isotope profiles of the different cores, some summer peaks that were only weakly visible in one core could be identified. Only in the uppermost parts of the cores is it difficult to unambiguously contribute peaks to summer maxima due to poorer core quality.

Figure 3 shows the results of the DEP measurements for the four cores G3, G4, G5 and M2. Generally, the data are quite noisy, and an independent dating would be very difficult. However, by combining DEP and the stable oxygen data of all cores, it is possible to identify peaks that are most likely caused by volcanoes. In G5, two striking peaks can be seen, which might be attributed to the volcanic eruptions of El Chichón, Mexico (1982), and Pinatubo, Philippines (1991). Identification of the peaks was supported by a comparison with the results of Kaczmarska and others (1994), who investigated a $100 \mathrm{~m}$ firn core in coastal DML. Whereas the possible El Chichón peak in the deepest layers of the cores is outstanding, the Pinatubo peak can only be found by assuming a certain depth range based on knowledge of accumulation rate from earlier studies and/or the stable-isotope measurements. These peaks can be used as absolute time markers (within the uncertainty range) for the calculation of a mean accumulation rate of the time period between the corresponding eruption and the drilling. The time of deposition of volcanic material is usually assumed to 

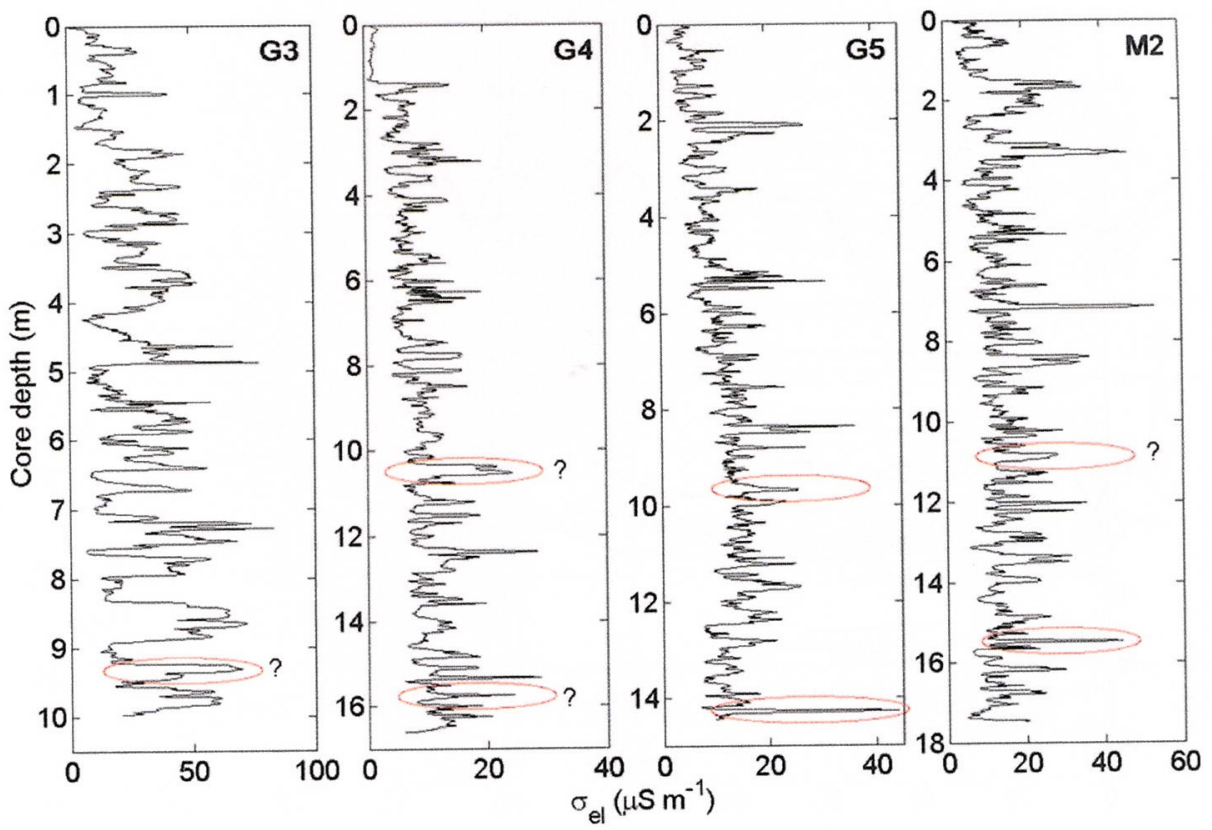

Fig. 2. $\delta^{18} \mathrm{O}$-depth profiles of firn cores G3, G4, G5 and M2.

be 1-2 years after the eruption. In G3, G4 and $M 2$ the conductivity exhibits fairly noisy behaviour, so an unambiguous identification of the volcanic signals is not possible. But by comparison with $\mathrm{G} 5$ these peaks can also be found in G3 and G4, though with relatively large uncertainties (i.e. several years), since several peaks of similar size are found in the corresponding depth range. In particular, the Pinatubo peak in core $\mathrm{G} 3$ can be questioned, because the $\delta^{18} \mathrm{O}$ dating of the core goes back to only 1993, whereas the Pinatubo signal is usually attributed to 1992 . However, some studies (e.g. Cole-Dai and others, 1997) state that the Pinatubo signal should be found in 1993. For both options the suggested peak is possible within the error bounds of the dating.
In Figure 4 we compare the dating using $\delta^{18} \mathrm{O}$ and DEP. The $\delta^{18} \mathrm{O}$ and conductivity of core $\mathrm{G} 3$ are shown together with the corresponding annual boundaries. The relatively strong peak in conductivity at $\sim 5 \mathrm{~m}$ depth was not counted as a summer layer since it corresponds to an extreme ice layer. A very thick ice layer was observed in all cores at about $5-6 \mathrm{~m}$ depth. The density is clearly much higher for that ice layer than for the surrounding firn and, thus, the permittivity peaks. As the permittivity influences the conductivity (Wilhelms, 2005), the peak in DEP conductivity at $\sim 5 \mathrm{~m}$ is most likely due to the massive ice layer and thus was not used for dating. Generally, the DEP dating yields a slightly higher age, since certain peaks are attributed to
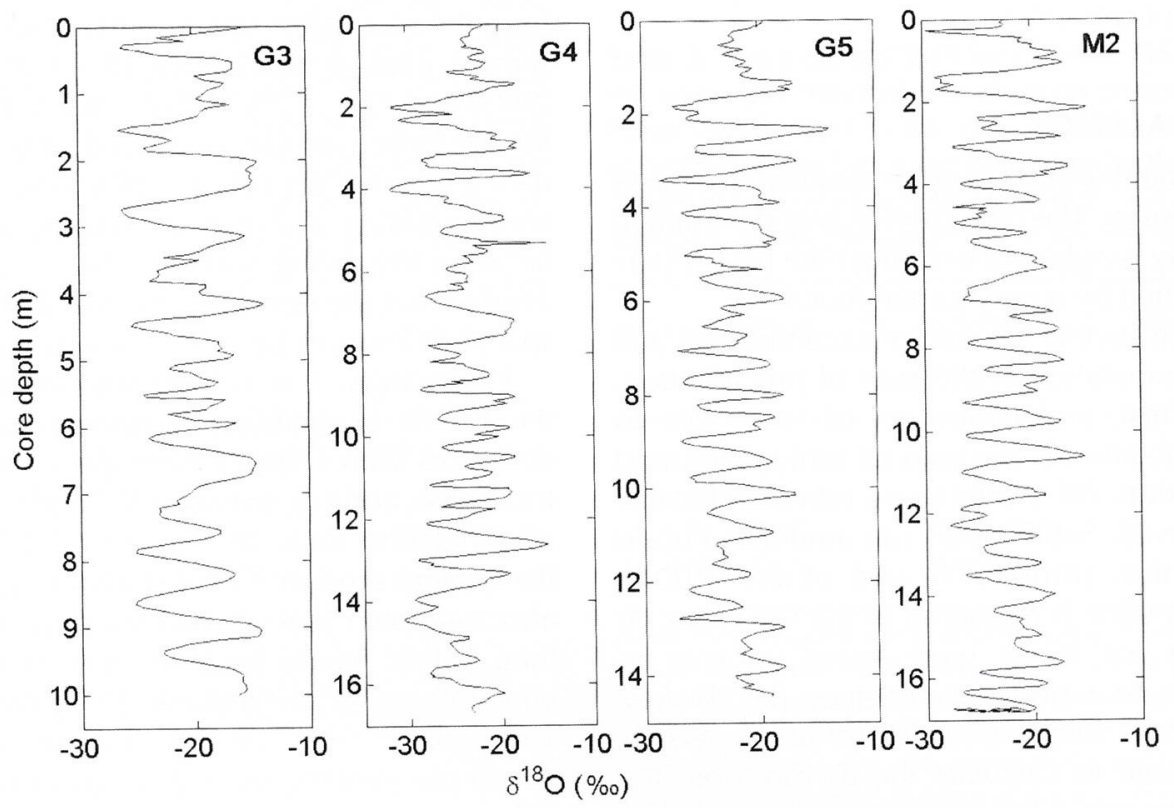

Fig. 3. Electrical conductivity from DEP from firn cores G3, G4, G5 and M2. Suggested volcanic horizons due to eruption of Pinatubo and El Chichón used for dating are marked with red circles. 

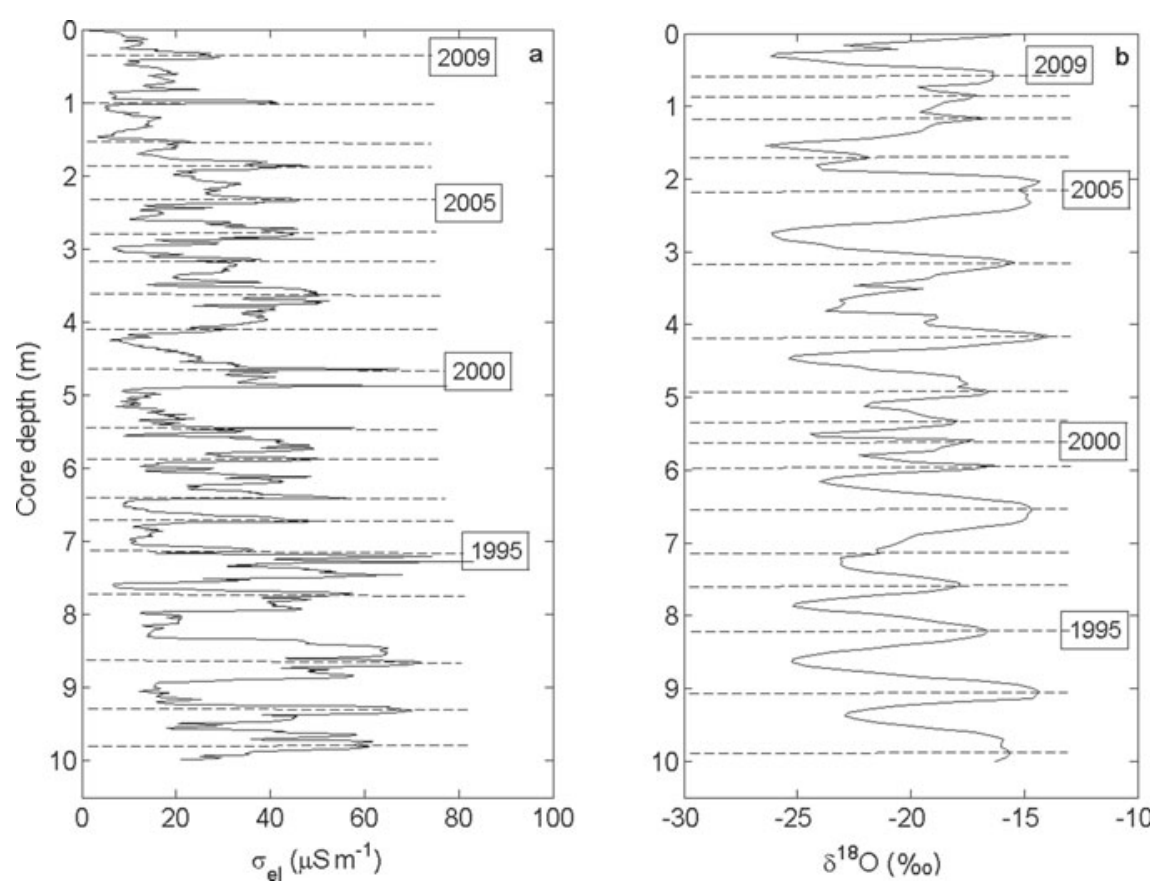

Fig. 4. Comparison of dating of $\mathrm{G} 3$ using DEP and $\delta^{18} \mathrm{O}$ measurements.

apparent summer maxima, though these might have different causes (e.g. high sea-salt concentrations connected to single storm events). This was also found by Schlosser and Oerter (2002a) for the dating of shallow cores from Ekströmisen. On average of all investigated firn cores, the age derived from DEP profiles was not more than $10 \%$ higher than that determined using stable isotopes.

In spite of some remaining ambiguities, for the reasons mentioned above the $\delta^{18} \mathrm{O}$ dating is more reliable than the DEP dating, with an estimated error of \pm 2 years for single years and approximately 3-4 years for the age of the core. This estimate stems from the number of annual layers whose $\delta^{18} \mathrm{O}$ variations could not be unambiguously identified as seasonal variations and the fact that some of the errors for single years counteract. Naturally the error also depends on the length/age of the core.

\section{SURFACE MASS BALANCE}

The SMB was calculated using dating by seasonal variations of $\delta^{18} \mathrm{O}$ and bulk density. The bulk density was determined directly in the field by weighing/measuring core pieces (10$50 \mathrm{~cm}$ length) smoothed by a polynomial function.

The SMB of the ice shelf is the sum of accumulation and ablation, where accumulation is the sum of precipitation, deposition of hoar-frost, and deposition of snow due to snowdrift, whereas ablation is the sum of sublimation and erosion due to snowdrift. All melted snow refreezes locally, so no runoff is observed. Sublimation can amount to up to $\sim 40 \%$ of precipitation (Bromwich and others, 2004). However, the SMB is what is measured in the firn cores. In all cores, numerous ice layers were found, ranging in thickness from $1 \mathrm{~mm}$ to several centimetres; the thickest ones reached $>10 \mathrm{~cm}$. Because of these ice layers, a polynomial fit was used to calculate the density from the bulk density measurements. It has been shown that the error in density influences the SMB much less than the dating error (Hawley and others, 2008). It is assumed that this melting happened within one annual layer during summer, so no mass transport from one annual layer to deeper layers occurred. These irregular ice layers also mean that it was not feasible to clearly identify the summer layer of 2008/09. (If there were one main ice layer, it would indicate the summer layer. The irregular thick ice layers could not be unambiguously related to the end of summer 2008/09.)

Figure 5 shows the SMB (using the $\delta^{18} \mathrm{O}$ dating) and mean annual $\delta^{18} \mathrm{O}$ for the four firn cores. Table 2 compares the mean annual accumulation rates for the time periods defined by the volcanic time markers based on the DEP measurements. These annual accumulations are calculated from the ratio of water equivalent depths above the identified volcanic time markers to the time-span covered by the firn column. The relative error estimates are derived from the root-mean-square sum of the relative errors due to sample mass determination of $\sim 1.4 \%$ (Karlöf and others, 2005 ) and $22 \%, 12 \%$ and $8 \%$ due to time-span uncertainty for the three periods considered, respectively. As a typical dating error for the volcanic horizons, a value of 1 year was used, yielding a 2 year uncertainty on the time interval between the dating horizons. Note that here we implicitly assume that the errors are independent. Table 2 shows that spatial differences between the single cores are $<15 \%$.

Interestingly, it is not the southernmost core that shows the lowest accumulation, whereas usually accumulation decreases with distance from the coast: G3, the northernmost core, and G5, between M2 and G4, have similarly low accumulation rates. In the case of G3 the reason is most likely wind erosion. Other studies of ice-shelf regions have also suggested that accumulation is lower near the coast than further inland because snow is lost to the ocean by wind influence (Swithinbank, 1957; Thomas, 1973; Isaksson and Karlén, 1994). The low accumulation at G5 could be due to precipitation differences connected to the orographic influence of an ice rise to the west, or due to wind influence (both erosion at the lower-accumulation site and increased deposition at the higher-accumulation site). Rotschky and 


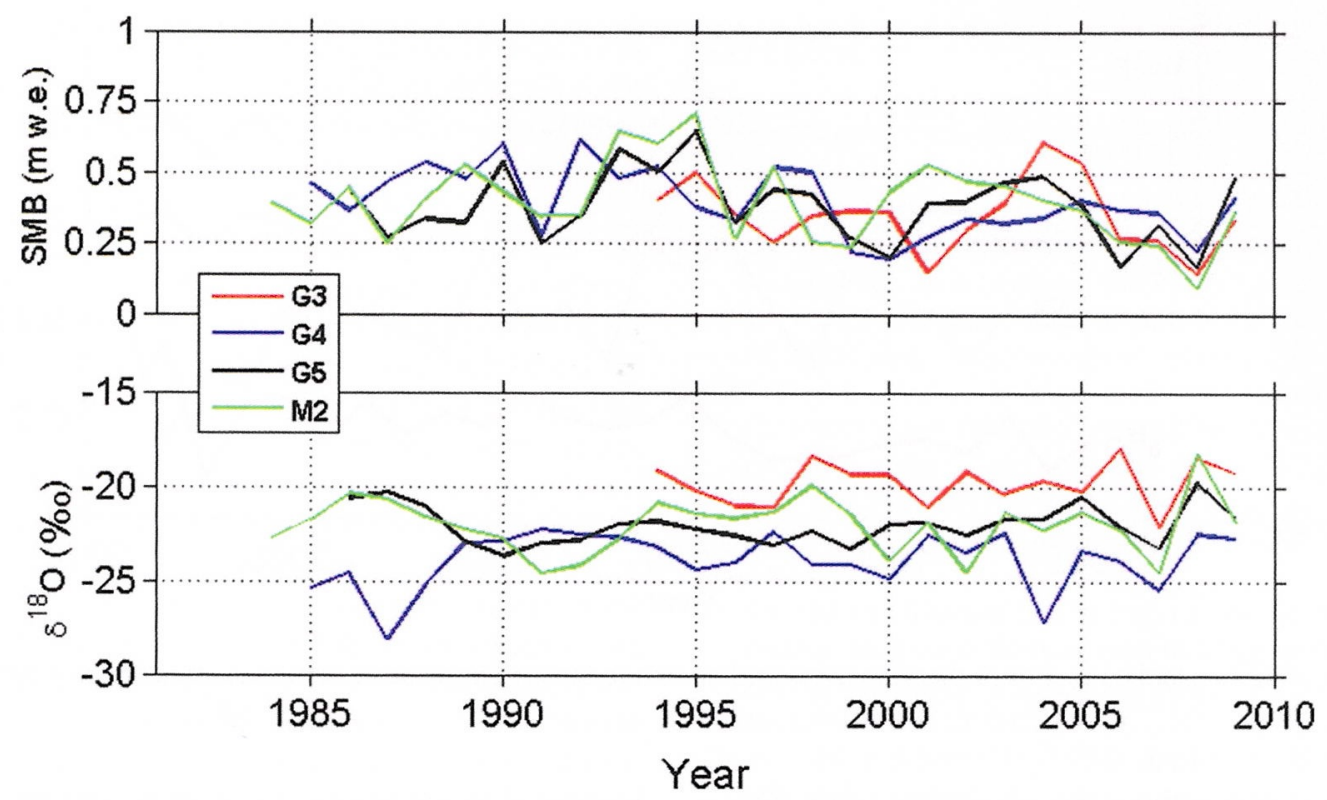

Fig. 5. Annual SMB and annual mean $\delta^{18} \mathrm{O}$ of cores $\mathrm{G} 3, \mathrm{G} 4, \mathrm{G} 5$ and $\mathrm{M} 2$.

others (2007) calculated an accumulation map for west DML using stake measurements, snow pits and firn cores from various expeditions. This map shows an eastwardreaching tongue of relatively high accumulation on Fimbulisen, with lower values to the north of it, which also means accumulation that increases with distance from the coast in a certain area.

Temporal variability of $\mathrm{SMB}$ is high: the interannual variability exceeds $30 \%$ of the mean annual SMB (see Table 2). Precipitation events and thus accumulation in coastal areas of Antarctica are caused by low-pressure systems moving from west to east above the ocean north of the coast. This precipitation is irregular and depends on the corresponding synoptic situations and the general atmospheric flow, which are both highly variable (e.g. King and Turner, 1997). Additionally, precipitation events are usually accompanied by strong winds, which also increases spatial variability of SMB due to blowing and drifting snow. Katabatic winds during dry periods can lead to both erosion of the snow surface and deposition of additional snow that is not related to precipitation but is part of the accumulation. (Although katabatic winds do not develop on ice shelves, they can still influence ice shelves with small north-south extent, especially at the southern boundaries.) Sublimation of blowing or falling snow represents a further

Table 2. Comparison of SMB of firn cores G3, G4, G5 and M2 for different time periods related to the suggested volcanic time markers (uncertainties in parentheses)

\begin{tabular}{lccc} 
Firn core & \multicolumn{3}{c}{ Accumulation } \\
& $1983-92$ & $1992-2009$ & $1983-2009$ \\
& mmw.e. & mmw.e. & mm w.e. \\
\hline G3 & - & $298(36)$ & - \\
M2 & $386(85)$ & $348(42)$ & $361(29)$ \\
G5 & $368(81)$ & $325(40)$ & $339(27)$ \\
G4 & $390(86)$ & $349(42)$ & $363(29)$ \\
\hline
\end{tabular}

mass loss. Thus usually not even closely neighboured cores show good agreement in accumulation rates (e.g. Fisher and others, 1985; Karlöf and others, 2005). It has been shown that, in spite of the high wind influence, $\delta^{18} \mathrm{O}$ values of cores drilled within a short distance usually agree much better than accumulation values. This is probably because the isotope ratios are relatively uniform during single precipitation events, whereas accumulation is dependent on wind and topography and can be altered even by extremely slight depressions or rises in the surface (Schlosser and Oerter, 2002a,b).

Fitting the straight lines to the annual SMB of the single cores as well as the stacked SMB series reveals a weak tendency to decreasing SMB at the core sites. However, only for core G4 was the trend in the SMB series found to be statistically significant at the $5 \%$ significance level. The

Table 3. Mean annual SMB for G3, M2, G5 and G4 together with the respective standard deviations (in parentheses). Magnitudes of linear trends fitted to the data and their standard deviations (in parentheses); the trends are calculated for the periods before 2007. Bold highlights the trend estimate for the G4 core series, which was detected statistically significant at the $5 \%$ significance level

\begin{tabular}{lccc} 
Firn core, period & $\begin{array}{c}\text { Accumulation }\left(\sigma_{\text {acc }}\right) \\
\text { mm w.e. }\end{array}$ & $\begin{array}{c}\text { Slope }\left(\sigma_{\text {slope }}\right) \\
\mathrm{mm} \mathrm{a}^{-1}\end{array}$ & $p$-value \\
\hline G3, 1993-2006 & $370(120)$ & $-1(8)$ & 0.89 \\
M2, 1983-2006 & $415(130)$ & $-2(4)$ & 0.57 \\
G5, 1985-2006 & $390(120)$ & $-3(4)$ & 0.54 \\
G4, 1984-2006 & $\mathbf{4 1 0 ( 1 2 0 )}$ & $\mathbf{- 8 ( 3 )}$ & $\mathbf{0 . 0 2}$
\end{tabular}

Notes: For testing procedure we used $F$ test with 1 and $n-2$ degrees of freedom (Draper and Smith, 1998), where $n$ is for the length of the respective time series. The test assesses utility of the proposed model using $F$ statistic defined here as $F=R^{2} /\left[\left(1-R^{2}\right) /(n-2)\right]$, where $R$ is the correlation coefficient between the model and the data. This is essentially a ratio of the 'explained' by the model to 'unexplained' variance of the data. $P$-value of the testing for 'notrend' null hypothesis $\left(H_{0}\right.$ : slope $\left.=0\right)$ is the probability of obtaining the $F$ statistic at least as high as was calculated purely by chance. If the value is $<0.05$, the hypothesis of 'no trend' can be rejected at the $5 \%$ significance level. 


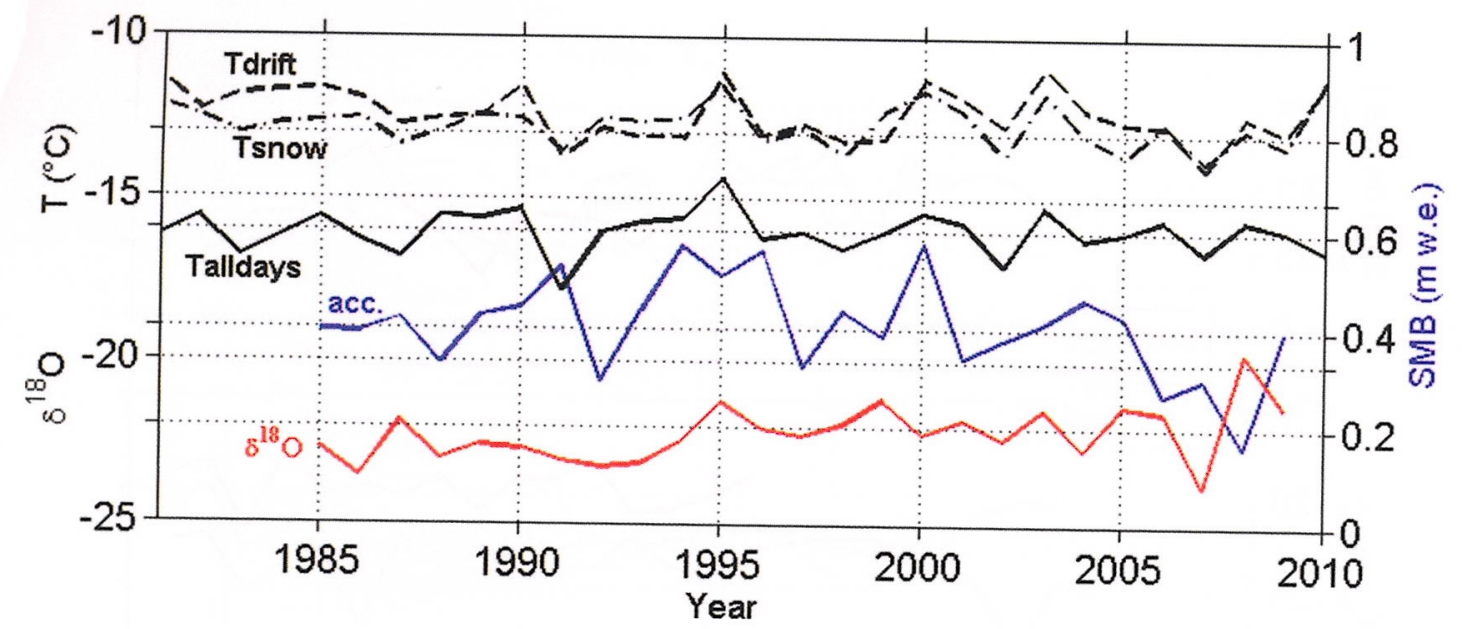

Fig. 6. Time series of $\delta^{18} \mathrm{O}$, stacked record of the four cores and annual mean air temperature (snowfall days only) of Neumayer station.

trends were calculated without the uppermost years 200709, which are likely to have the largest dating errors. The corresponding SMB values and trends for these time periods are shown in Table 3, where more details of the linear regression analysis applied are also given. One should note that this analysis does not take into account the potential effect of dating errors on the records, which are translated into uncertainties in the estimated annual SMB. Although we do not quantify the associated error variances here, introducing them into the regression analysis would further increase the uncertainty of the estimates of the slopes of the regression lines. This implies that the outputs of the testing procedure (see Table 3 ) are even less conservative than they are supposed to be.

\section{Stable-isotope ratios, accumulation and air temperature}

It is not relevant to discuss spatial variability of the stableisotope ratios based on only four cores. However, as can be seen in Table 1, the southernmost core, G4, has the lowest isotope ratio, as would be expected due to the continentality effect. The lowest $10 \mathrm{~m}$ firn temperature measured in the borehole, which is supposed to represent the mean annual temperature at the site, is not observed at G4, but at G5, while G4 is warmer than both G5 and M2. However, the differences amount to only tenths of ${ }^{\circ} \mathrm{C}$ and might be partly due to measuring errors in the same order of magnitude. (The thermistor strings were usually left in the borehole overnight before being read, but the minimum measuring time was at least 1 hour.)

A linear relationship is found between mean annual stable oxygen ratios of snow/ice and the annual mean air temperature at the deposition site, although this ratio depends in a complex way on precipitation history (moisture source and transport, evaporation and condensation processes during transport) (Dansgaard, 1964). In ice-core science it is generally assumed that stable oxygen isotope ratios and accumulation rates are positively correlated due to the dependence of saturation vapour pressure on air temperature and the linear relationship between $\delta^{18} \mathrm{O}$ and temperature (Dansgaard, 1964). However, several studies (e.g. Noone and Simmonds, 1998; Divine and others, 2009) have shown that this assumption cannot be generalized. Figure 6 presents the stacked records of mean annual stable oxygen isotope ratios $\left(\delta^{18} \mathrm{O}\right)$ and $\mathrm{SMB}$ of the four cores compared to the annual mean air temperature of Neumayer station. In this case, we simply calculated the arithmetic mean of all cores, because they are all situated close together in the same temperature regime. Back to 1993 it is the mean of all four cores; before that, the number of cores decreases corresponding to the age of the cores. Since the stable-isotope ratios in the core represent only time periods with snowfall, we calculated a 'snowfall temperature' using the 3 hourly SYNOP observations. However, due to the high wind speeds that accompany the snowfall events, it is often not possible to distinguish between snowfall and blowing snow. Thus two curves are shown here: one is the mean air temperature for all SYNOP data where snowfall was observed; the other combines observations of snowfall and blowing snow. Both curves are fairly similar and the values are $\sim 5^{\circ} \mathrm{C}$ higher than the mean over all days (lower curve). Neither the snowfall temperature nor the $\delta^{18} \mathrm{O}$ shows any significant trend, whereas accumulation is slightly decreasing. Temperature and $\delta^{18} \mathrm{O}$ generally show a similar picture, with a distinct minimum in 2007 that can also be seen in all single cores (Fig. 5). We did not calculate a correlation coefficient, since the quality of the correlation is strongly influenced by uncertainties in the dating. It would only be feasible if the cores were longer so that a running mean over several years could be calculated.

\section{DISCUSSION AND CONCLUSION}

Dating of the firn cores using stable-isotope ratios and DEP measurements yields results consistent within the error bounds of both methods. The DEP measurements were used in spite of their low signal-to-noise ratio, since by comparison with previous measurements and the stable-isotope profiles, volcanic horizons can be identified that can be used as absolute time markers, which cannot be derived from the $\delta^{18} \mathrm{O}$ values.

Measurements of $\mathrm{SMB}$ and stable oxygen isotope ratios $\left(\delta^{18} \mathrm{O}\right)$ of shallow firn cores on Fimbulisen show that in the past 25 years the $\delta^{18} \mathrm{O}$ values have been fairly stable, whereas the SMB shows a weak decreasing trend, although this is statistically significant in only one of the cores. Finding the statistically significant trend for only one of four series in the area should be interpreted with caution. It is also important to remember that the estimated trend magnitudes are generally functions of the time period 
considered. We therefore suggest that with the data at hand our analysis does not provide any robust evidence for the long-term tendency in SMB in the study area. One should stress that our findings are for the period considered only and do not indicate anything in a longer-term perspective.

Comparison with an older, longer core taken on Fimbulisen in 2000 (S100 (Fig. 1b); Kaczmarska and others, 2004) shows, however, that this trend was already evident throughout the 20th century. This is also confirmed by Schlosser and Oerter (2002b), who found a decreasing trend in core B04, drilled in 1981 near Neumayer station (see Fig. 1b), which also shows a statistically significant trend since $1892 . \delta^{18} \mathrm{O}$ is assumed to be linearly related to air temperature, but is influenced by many other factors, of which seasonality of precipitation is one of the most important and can lead to a strong bias in the temperature signal, or even to a complete loss of this positive correlation or to anticorrelation (Noone and Simmonds, 1998; Noone and others, 1999; Schlosser, 1999; Divine and others, 2009). The relationship between air temperature and accumulation is much more complex than previously thought. The use of a simple linear relationship between accumulation rate and air temperature in flow models used for ice-core dating can thus lead to large errors. It is almost meaningless to attempt to derive a temperature trend for the entire Antarctic continent, since for large areas no longterm, in situ climate measurements are available (Turner and others, 2002). The trends from the various stations show a spatially complex picture of change across the continent during recent decades and do not indicate any consistent warming or cooling (Turner and others, 2002). The weak temperature trends observed at different locations in the past 50 years in Antarctica (Turner and others, 2002, 2005) have been related to the Southern Annular Mode (SAM; Marshall, 2003), which describes the climate mode of the Southern Ocean dependent on the meridional gradient in air pressure (e.g. $40-65^{\circ} \mathrm{S}$ ). A large pressure gradient (SAM in its high-index state) means a mainly zonal atmospheric flow, hence little meridional transport of heat and moisture, hence lower temperature and accumulation in most parts of Antarctica. The influence of SAM on accumulation is poorly understood so far.

Deeper firn cores from Fimbulisen, covering the past 100 years, are desirable in order to be able to calculate statistically significant trends. A better understanding of the relationship between accumulation and temperature is necessary for both correct dating of deep ice cores and to assess the future evolution of the $\mathrm{SMB}$ and solid ice dynamics of the Antarctic ice sheet and their contribution to sea-level rise.

\section{ACKNOWLEDGEMENTS}

We are grateful to all members of the Fimbulisen Expedition 2009/10 for support in the field. Neumayer SYNOP data were kindly provided by Gert König-Langlo of the Alfred Wegener Institute, Bremerhaven, Germany. We thank two anonymous reviewers and the scientific editor, Michiel van den Broeke, for constructive criticism. This study was financed by the Norwegian Research Council through NARE, the Centre for Ice, Climate and Ecosystems (ICE) at the Norwegian Polar Institute, the Estonian Target Financing Project SF0320080s07 and the Austrian Science Funds (FWF; grant V31-N10).

\section{REFERENCES}

Anschütz $\mathrm{H}$ and 7 others (2009) Revisiting sites of the South Pole Queen Maud Land Traverses in East Antarctica: accumulation data from shallow firn cores. J. Geophys. Res., 114(D24), D24106 (doi: 10.1029/2009JD012204)

Bromwich DH, Guo Z, Bai L and Chen Q (2004) Modelled Antarctic precipitation. Part I: spatial and temporal variability. J. Climate, 17(3), 427-447 (doi: 10.1175/1520-0442(2004)017<0427:MAP$\mathrm{PIS}>2.0 . \mathrm{CO} ; 2)$

Cole-Dai J, Mosley-Thompson E and Thompson LG (1997) Quantifying the Pinatubo volcanic signal in south polar snow. Geophys. Res. Lett., 24(21), 2679-2682 (doi: 10.1029/ 97GL02734)

Dansgaard W (1964) Stable isotopes in precipitation. Tellus, 16(4), 436-468

Divine DV and 8 others (2009) Tropical Pacific-high latitude south Atlantic teleconnections as seen in $\delta^{18} \mathrm{O}$ variability in Antarctic coastal ice cores. J. Geophys. Res., 114(D11), D11112 (doi: 10.1029/2008JD010475)

Draper NR and Smith H (1998) Applied regression analysis, 3rd edn. Wiley, New York

Fisher DA, Reeh N and Clausen HB (1985) Stratigraphic noise in the time series derived from ice cores. Ann. Glaciol., 7, 76-83

Glen JW and Paren JG (1975) The electrical properties of snow and ice. J. Glaciol., 15(73), 15-38

Hawley RL, Morris EM and McConnell JR (2008) Rapid techniques for determining annual accumulation applied at Summit, Greenland. J. Glaciol., 54(188), 839-845 (doi: 10.3189/ $002214308787779951)$

Isaksson E and Karlén W (1994) Spatial and temporal patterns in snow accumulation, western Dronning Maud Land, Antarctica. J. Glaciol., 40(135), 399-409

Isaksson E and Melvold K (2002) Trends and patterns in the recent accumulation and oxygen isotopes in coastal Dronning Maud Land, Antarctica: interpretations from shallow ice cores. Ann. Glaciol., 35, 175-180 (doi: 10.3189/172756402781817356)

Jenkins A and 6 others (2010) Observations beneath Pine Island Glacier in West Antarctica and implications for its retreat. Nature Geosci., 3(7), 468-472 (doi: 10.1038/ngeo890)

Kaczmarska M and 10 others (2004) Accumulation variability derived from an ice core from coastal Dronning Maud Land, Antarctica. Ann. Glaciol., 39, 339-345 (doi: 10.3189/ 172756404781814186)

Kaczmarska M and 7 others (2006) Ice core melt features in relation to Antarctic coastal climate. Antarct. Sci., 18(2), 271-278 (doi: 10.1017/S0954102006000319)

Karlöf L and 11 others (2005) Accumulation variability over a small area in east Dronning Maud Land, Antarctica, as determined from shallow firn cores and snow pits: some implications for icecore records. J. Glaciol., 51(174), 343-352 (doi: 10.3189/ $172756505781829232)$

King JC and Turner J (1997) Antarctic meteorology and climatology. Cambridge University Press, Cambridge

Lunde T (1961) On the snow accumulation in Dronning Maud Land. Den Norske Antarktisekspedisjonen, 1956-60. Scientific Results 1. Nor. Polarinst. Skr. 123

Marshall GJ (2003) Trends in the Southern Annular Mode from observations and reanalyses. J. Climate, 16(24), 4134-4143

Melvold K (1999) Impact of recent climate on glacier mass balance: studies on Kongsvegen, Svalbard and Jutulstraumen, Antarctica (DSc thesis, University of Oslo)

Melvold K, Hagen JO, Pinglot JF and Gundestrup N (1998) Large spatial variation in accumulation rate in Jutulstraumen ice stream, Dronning Maud Land, Antarctica. Ann. Glaciol., 27, 231-238

Monaghan AJ and 15 others (2006) Insignificant change in Antarctic snowfall since the International Geophysical Year. Science, 313(5788), 827-831 (doi: 10.1126/science.1128243) 
Monaghan AJ, Bromwich DH, Chapman W and Comiso JC (2008) Recent variability and trends of Antarctic near-surface temperature. J. Geophys. Res., 113(D4), D04105 (doi: 10.1029/ 2007JD009094)

Moore JC, Mulvaney R and Paren JG (1989) Dielectric stratigraphy of ice: a new technique for determining total ionic concentrations in polar ice cores. Geophys. Res. Lett., 16(10), 1177-1180

Neethling DC (1970) Snow accumulation on the Fimbul ice shelf, western Dronning Maud Land, Antarctica. IASH Publ. 86 (Symposium at Hanover 1968 - Antarctic Glaciological Exploration (ISAGE)), 390-404

Noone D and Simmonds I (1998) Implications for the interpretation of ice-core isotope data from analysis of modelled Antarctic precipitation. Ann. Glaciol., 27, 398-402

Noone D, Turner J and Mulvaney R (1999) Atmospheric signals and characteristics of accumulation in Dronning Maud Land, Antarctica. J. Geophys. Res., 104(D16), 19191-19211

Oerlemans J (1982) Response of the Antarctic ice sheet to a climate warming: a model study. J. Climatol., 2(1), 1-11 (doi: 10.1002/ joc.3370020102)

Rolstad C, Whillans IM, Hagen JO and Isaksson E (2000) Largescale force budget of an outlet glacier: Jutulstraumen, Dronning Maud Land, East Antarctica. Ann. Glaciol., 30, 35-41 (doi: 10.3189/172756400781820642)

Rotschky G and 6 others (2007) A new surface accumulation map for western Dronning Maud Land, Antarctica, from interpolation of point measurements. J. Glaciol., 53(182), 385-398 (doi: 10.3189/002214307783258459)

Schlosser E (1999) Effects of seasonal variability of accumulation on yearly mean $\delta^{18} \mathrm{O}$ values in Antarctic snow. J. Glaciol., 45(151), 463-468
Schlosser E and Oerter H (2002a) Shallow firn cores from Neumayer, Ekströmisen, Antarctica: a comparison of accumulation rates and stable-isotope ratios. Ann. Glaciol., 35, 91-96 (doi: 10.3189/172756402781816915)

Schlosser E and Oerter H (2002b) Seasonal variations of accumulation and the isotope record in ice cores: a study with surface snow samples and firn cores from Neumayer station, Antarctica. Ann. Glaciol., 35, 97-101 (doi: 10.3189/172756402781817374)

Swithinbank C (1957) Glaciology I(B). The regime of the ice shelf at Maudheim as shown by stake measurements. NorwegianBritish-Swedish Antarct. Exped., 1949-52, Sci. Res. 3. Norsk Polarinstitutt, Oslo, 41-76

Thomas RH (1973) The dynamics of the Brunt Ice Shelf, Coats Land, Antarctica. Br. Antarct. Surv. Sci. Rep. 79

Turner J, King JC, Lachlan-Cope TA and Jones PD (2002) Recent temperature trends in the Antarctic. Nature, 418(6895), 291-292 (doi: 10.1038/418291b)

Turner J and 8 others (2005) Antarctic climate change during the last 50 years. Int. J. Climatol., 25(3), 279-294 (doi: 10.1002/ joc.1130)

Van den Broeke MR and 6 others (1999) Climate variables along a traverse line in Dronning Maud Land, East Antarctica. J. Glaciol., 45(150), 295-302

Wilhelms $F$ (2005) Explaining the dielectric properties of firn as a density-and-conductivity mixed permittivity (DECOMP). Geophys. Res. Lett., 32(16), L16501 (doi: 10.1029/ 2005GL022808)

Wilhelms F, Kipfstuhl J, Miller H, Heinloth $\mathrm{K}$ and Firestone J (1998) Precise dielectric profiling of ice cores: a new device with improved guarding and its theory. J. Glaciol., 44(146), $171-174$ 